\title{
TOURISM DEPARTMENT STRATEGY OF PRESERVING ART AND CULTURE IN MEDAN CITY AT GELAR MELAYU SERUMPUN EVENT (GeMeS)
}

\author{
Hafiza Azura ${ }^{1}$, Dr. Wan Anayati, M.A ${ }^{2}$ \\ English Department, Fakultas Bahasa dan Komunikasi, Universitas Harapan Medan \\ Jalan Imam Bonjol, No.35 Medan, 20151, Sumatera Utara-Indonesia
}

\begin{abstract}
The objective of this thesis are: to find out the implementation of the persuasive language used in the promotion strategy of Gelar Melayu Serumpun (GeMeS), and to find out the persuasive language occure in Gelar Melayu Serumpun (GeMeS). The research design used in this study is descriptive qualitative method. The data analysis of this thesis are library research, brochures, articles, invitation letters and social media. The data used in this study are the persuasive language of the Medan City Tourism Office as the organizer of the GeMeS event totaling three informant. The informant as the employee of Medan City Tourism Office is needed to complete the data. The persuasive language carried out by the GeMeS event organizers occure by distribusing various form of promotional media such as brochures, articles, invitation letters and social media. Medan City Tourism Office.The result showed that the implementation of the persuasive language used in the promotion strategy of the Serumpun Malay title (GeMeS) was divided into three parts, namely advertising persuasion, propaganda persuasion, and education persuasion.
\end{abstract}

Keywords: Strategy, Promotion, Arts and Malay Culture, and Persuasion Language. 


\section{Introduction}

Medan City is the capital of North Sumatra province. It has the title of the third-largest city after Jakarta and Surabaya, which is known as a tourist destination that has a very diverse and fantastic tourism potential with unique characteristics. Besides that, the arts and culture in Medan City also represent various ethnicities from the people living in Medan City. The rapid development of globalization impacts each region to compete to highlight their regional identity through their arts and culture and package local potentials to make them more attractive than other areas.

One form of promotion that the Medan City Tourism Office is being carried out in promoting the preservation of Medan's distinctive arts and culture is the "GeMeS" Malay Serumpun Movement program. GeMeS is a Malay cultural event held at the Maemoon Palace in Medan. The event concept is a colossal Malay dance performance and Malay cultural arts performances from 5 different countries and ten provinces in Indonesia and North Sumatra. In 2019, GeMeS was attended by participants from allied countries such as Malaysia, Brunei Darussalam, Thailand, Singapore, and South Korea. The participants from various provinces were added, including Yogyakarta, West Java, West Sumatra, Lampung, Riau, Bengkulu, Nangroe Aceh Darussalam, and Jambi.

Besides, participants from other regencies/cities in North Sumatra such as Binjai, Tebing Tinggi, Labuhan Batu Utara, Langkat, Deli Serdang and Batu Bara will also be enlivened by the performance of the capital city artist D ' Academies, namely Deswa, Ayu, Alibi, Intan Baiduri and Lusi KDI, are ready to entertain guests and attendees with dangdut and Malay music. The GeMeS event is also supported by all Regional Apparatus Organizations (OPD) within the Pemko Medan so that they can help and socialize through the media that Gemes does highlight not only the arts and culture of one ethnicity but also the unity of cultural arts that exist throughout the archipelago with Malay nuances. GeMeS itself aims to highlight the local wisdom of the distinctive culture of Medan City as a primary culture to become a tourist attraction force for Medan City. Although Medan City has a multi-ethnic culture, geographically, Medan City has a local culture, namely Malay culture.

Of course, in implementing the GeMeS program, there is a role for strategy and promotion used through advertising media. The advertisement must use good grammar to understand the aims and objectives of the GeMeS program. Besides, good grammar is also carried out by the Medan City Tourism Office by persuading contingents from outside the country, such as Malaysia, Singapore, Thailand and other Southeast Asian countries, to attend and participate in implementing the event by giving an official invitation. Starting from the way of writing the language, the media used, the banqueting process to the services performed, they must use good grammar so that the contingent from abroad is satisfied with the benefits of the Medan City Tourism Office.

Based on research conducted by Jalilifar, according to the theory of Patpong (2009) in Jalilifar (2019: 213), the use of language in advertising is one example to show the use of persuasive speech. However, Pakpong only explained advertising in general, not specifically in the tourism sector. Promotion in the language is the main thing in conveying information about something that is being implemented. The delivery process and good grammar, of course, will attract public attention. Language is the primary key to strategic planning and promotion undertaken. 
This is also in line with Maulina (2018) research, which explains that the language of persuasion in advertising has the nature of providing information, persuading, inviting, giving advice, and even influencing consumers to be interested in following the wishes of the producers. Ads with the right level of persuasion will also play a significant role in shaping a trend and trend and even forming an awareness and construction of one's thinking. The characteristics of persuasion language are persuasion or an invitation to do something. A paragraph or essay containing elements of influence is usually used to support politics, education, advertising and propaganda.

Specifically, based on the results of research conducted by Nainggolan et al. (2020: 27), persuasive language is the language used to persuade and influence consumers to follow and tend to do what producers ask or say. The way that can be done so that the language of persuasion achieves its goals is to use language in invitations, suggestions, suggestions or input, commands, and affirmations as examples of the languages used in print media advertisements.

Then, based on Hassan's (2017) research, like other promotional materials, tourism promotion can be printed or printed in electronic form. One of the main functions of a tourism promotion tool is describing one's country through self-presentation using a tourism language style. Like other promotional materials, tourism promotion can be printed or printed in electronic form. One of the main functions of a tourism promotion tool is describing one's country through selfpresentation using a tourism language style.

In another study conducted by Tunggala \& Saadjad (2019: 199), promoting an in-depth understanding of the market is needed, which then becomes the basis for formulating promotional strategies and programs. The existence of mass media in promoting tourist objects can lead to effective communication. Besides, the promotion also requires a publicity strategy, a whole unit of methods by using various media as a tool that is assisted by psychological factors, sociodemographic statistics and research to spread ideas, sell products and make the organization known. It also optimized their tourism gimmicks through print and electronic media and online media with their respective mottos. For this reason, the use of print and electronic media and online media is a communication strategy in the promotion of tourist objects, where the aim is not only to inform but to persuade tourists so that the tourists concerned have the desire to come to visit the promoted area.

Based on these data and descriptions, the researcher would like to examine further the promotional strategies used by the Medan City Tourism Office in the process of organizing the GeMeS event as well as the grammar used in promoting the event and inviting contingents from abroad to attend and participate in the GeMeS event. The purpose of the research carried out by the researcher was to find out how the form of promotion strategy carried out by the Medan City Tourism Office in the implementation program of the Malay Allied Movement (GeMeS) in Medan City and to find out how the use of grammar carried out by the Medan City Tourism Office in spreading promotions using Systematic theory. Function Language (SFL).

\section{Method}

The research design used by the researcher is qualitative. According to Sugiyono (2013: 13), qualitative research is a new research method. This is because qualitative research is called a study based on the philosophy of postpositivism. Qualitative research can also be naturalistic research because it is carried out in natural conditions or what is said to be a natural setting. Qualitative research views social reality as complex, dynamic, full of meaning and has interactive 
relationship symptoms. Research is also conducted on natural objects, which develop as they are, not manipulated by researchers, and researchers' presence does not affect these objects' dynamics.

In this study, research participants were employees or staff/employees of the Medan City Tourism Office, who took part in the Malay Serumpun Movement (GeMeS) event in 2019, totaling three participants. The data collection technique is done by interview, observation and documentation. The data analysis used in this study is: observing data from the Serumpun Malay Movement (GeMeS) event, making a structured interview list so that when conducting interviews more focused and not running away from the research objectives, providing interview assistance tools such as stationery or recordings to help copy the results of interviews, describe the results of research starting from the profile of the Tourism Office, the characteristics of research informants, research results and discussion of research data as well as drawing conclusions and providing suggestions.

\section{Result and Discussion}

\section{The implementation of the persuasive language used in the promotion strategy of Titles} Melayu Serumpun (GeMeS)

This section will describe the research findings and analyze the persuasive speech of the promotion strategy found in the invitation letter from the Medan City Tourism Office to the Italian Ambassador and the framework of reference made by the Medan City Tourism Office related to the GeMeS event. The parts of the persuasion language used by the Medan City Tourism Office to the Italian Ambassador and the framework of reference include:

First, advertising persuasion. Persuasion Advertising is a persuasion paragraph used for commercial purposes or as an advertisement for a product. This persuasion paragraph's primary goal is to introduce and persuade readers to buy the products offered through this paragraph. This paragraph is usually used by parties who want to promote and sell their products. In the research that has been carried out by researchers, it can be analyzed that the form of advertising persuasion can be found in the invitation letter sent by the Medan City Tourism Office to the Italian Ambassador to be later translated and transmitted to countries invited to participate in the GeMeS event as well as the frame of reference. Medan City Tourism Office. The words summarized in the language of propaganda persuasion are:

a. On the first page of the invitation letter addressed to the Italian Ambassador, there is the word "Participant".

Which explains that there are certain criteria for contingents who wish to participate in the GeMeS event, such as contingents who have the same ethnic Malay in Medan City, both province and country as well as contingents. Those who are entitled to participate in the GeMeS event are the provinces or countries invited by the Medan City Tourism Office. So the participants who attended were not for all public circles, but more to the invited countries.

b. "To preserve Malay arts and culture which are world heritage as a tourist attraction in each region".

The meaning of this sentence is that Malay culture is a culture that has various ethnic types. For example, the Malay culture of Deli (Medan City) and Malay culture from Malaysia, then Malay culture from Brunei Darussalam, and Malay culture from other provinces such as Jambi, Pekan Baru, Palembang, and so on have many significant 
differences. Not only culture, types of dances, various dance movements, types of songs, food, and so on, also have significant differences between one Malay culture and another. Therefore, Malay culture is designated as a world heritage. This is because, only within the scope of Malay culture, there are many different kinds of customs and if studied specifically, have their uniqueness and characteristics.

c. On the first page of the framework of reference, the form of the first propaganda persuasion sentence : "Not the Lost Malays in the World"

The meaning of the word explains that Malay culture is a culture that has spread throughout the world. Malay culture does not only exist in North Sumatra, even other provinces and neighboring countries, and Malay culture will never disappear or die in this world. With this unique Malay slogan, and always used every time there is a Malay event, at this GeMeS event, the Medan City Tourism Office also wants to preserve Malay culture from all provinces and neighboring countries by holding the GeMeS event with the hope of gathering and inviting All publics who are familiar with Malay culture can broaden their knowledge of art workers and arts workers in Medan City to deepen Malay culture and as a comparison material for cultural preservation.

d. In the framework of reference, the form of the word propaganda persuasion is "Attraction".

Attractions are the types of activities offered related to tourism. Here the meaning of the attraction stated in the framework of reference for the Medan City Tourism Office is intended as a cultural attraction which is a performance of dance and songs from Malay culture that will be performed by all contingents participating in the GeMeS event.

e. The next form of the word propaganda persuasion is "Accessibility".

Accessibility is an easy way to achieve a goal, which concerns comfort, safety, and travel time. This is important to note because the higher the accessibility, the easier it is to reach, and the higher the level of comfort for tourists to come to visit. Here the meaning of accessibility stated in the framework of reference for the Medan City Tourism Office is intended as a form of accommodation as well as facilities and infrastructure provided by the Medan City Tourism Office to foreign tourists who are contingents at the GeMeS event. Based on the results of interviews with research informants, it is known that the form of accommodation, facilities, and infrastructure provided is the transportation of foreign contingents from when they arrive at the airport, lodging (hotels), lunch and dinner, and tour guides (LO) to help. the overseas contingents were in Medan City when they arrived until they returned to their respective countries.

f. The next form of the word propaganda persuasion is "Amenity".

Amenity is the availability and condition of existing facilities or provided for tourists during their trip. Here the meaning of amenity as stated in the framework of reference for the Medan City Tourism Office is intended as what the GeMeS event organizers provide in the context of carrying out activities for performing arts and cultural Malays, such as food stands and performance stands for songket cloth typical of Malay culture, micro-businesses, seats for all guests, stages, changing rooms and so on.

g. The form of the word propaganda persuasion found in other terms of reference is "The Malay Culture Study Project".

The meaning of this sentence is that the GeMeS event which from 2016-2019 was held based on a Malay cultural study project that has been implemented since 1972 . The basic concept remains the same, developing, extracting information, and preserving Malay culture so that later it will reach the next generation of Malay culture. will 
disappear in the swallow of the earth, following the Malay cultural slogan above"Malays will not disappear in the world".

h. Another form of persuasion propaganda that is mostly found in terms of reference, invitation letters to the Italian Ambassador, and the GeMeS Event brochure is the word "Serumpun".

The serumpun word in the Big Indonesian Dictionary means one ancestor or one lineage. In Malay culture, the word serumpun has the meaning of one unity, which means that even though they have different customs, different cultures of ethnic Malays still declare themselves to be a family when they meet other ethnic Malays. Therefore, in the invitation letter and the extension of the GeMeS event, the word serumpun means that the series of GeMeS events are only a series of activities that are Malay culture in nature. Then, the organization and participation of the contingent from within the city, outside the city, or abroad are people with ethnic Malay Culture or people and art workers who understand Malay culture.

Based on the results of this analysis, it can be concluded that the form of propaganda persuasion words or sentences in the invitation made by the Medan City Tourism Office is a form of confirmation of the GeMeS event which will be held in Medan City, starting from the meaning of the slogan, affirming the promotional language and all things given by the Medan City Tourism Office and received by tourists who are contingent for the GeMeS event.

Second, the language of propaganda persuasion. Persuasion Propaganda is a persuasion paragraph that contains an appeal that is conveyed very loudly and clearly so that the reader follows the appeal. This paragraph can usually be found in several prints and online media, such as magazines, newspapers, and articles on the internet or online media. Propaganda persuasion can also be used to express implicit meanings or messages that give a specific meaning and purpose. In the research that has been carried out by researcher, the data can be analyzed that the form of propaganda persuasion can be used in the invitation letter sent by the Medan City Tourism Office to the Italian Ambassador to be later translated and sent to the countries invited to participate in the GeMeS event as well as the terms of reference. Medan City Tourism Office. The form of the persuasion sentence or paragraph includes:

a. On the first page of the invitation letter addressed to the Italian Ambassador, there is the word "Participant".

Which explains that there are certain criteria for contingents who wish to participate in the GeMeS event, such as contingents who have the same ethnic Malay in Medan City, both province and country as well as contingents. Those who are entitled to participate in the GeMeS event are the provinces or countries invited by the Medan City Tourism Office. So the participants who attended were not for all public circles, but more to the invited countries.

b. "To preserve Malay arts and culture which are world heritage as a tourist attraction in each region".

The meaning of this sentence is that Malay culture is a culture that has various ethnic types. For example, the Malay culture of Deli (Medan City) and Malay culture from Malaysia, then Malay culture from Brunei Darussalam, and Malay culture from other provinces such as Jambi, Pekan Baru, Palembang, and so on have many significant differences. Not only culture, types of dances, various dance movements, types of songs, food, and so on, also have significant differences between one Malay culture and another. Therefore, Malay culture is designated as a world heritage. This is because, only within the scope of Malay culture, there are many different kinds of customs and if studied specifically, have their uniqueness and characteristics.

c. On the first page of the framework of reference, the form of the first propaganda persuasion sentence : "Not the Lost Malays in the World" 
The meaning of the word explains that Malay culture is a culture that has spread throughout the world. Malay culture does not only exist in North Sumatra, even other provinces and neighboring countries, and Malay culture will never disappear or die in this world. With this unique Malay slogan, and always used every time there is a Malay event, at this GeMeS event, the Medan City Tourism Office also wants to preserve Malay culture from all provinces and neighboring countries by holding the GeMeS event with the hope of gathering and inviting All publics who are familiar with Malay culture can broaden their knowledge of art workers and arts workers in Medan City to deepen Malay culture and as a comparison material for cultural preservation.

d. In the framework of reference, the form of the word propaganda persuasion is "Attraction".

Attractions are the types of activities offered related to tourism. Here the meaning of the attraction stated in the framework of reference for the Medan City Tourism Office is intended as a cultural attraction which is a performance of dance and songs from Malay culture that will be performed by all contingents participating in the GeMeS event.

e. The next form of the word propaganda persuasion is "Accessibility".

Accessibility is an easy way to achieve a goal, which concerns comfort, safety, and travel time. This is important to note because the higher the accessibility, the easier it is to reach, and the higher the level of comfort for tourists to come to visit. Here the meaning of accessibility stated in the framework of reference for the Medan City Tourism Office is intended as a form of accommodation as well as facilities and infrastructure provided by the Medan City Tourism Office to foreign tourists who are contingents at the GeMeS event. Based on the results of interviews with research informants, it is known that the form of accommodation, facilities, and infrastructure provided is the transportation of foreign contingents from when they arrive at the airport, lodging (hotels), lunch and dinner, and tour guides (LO) to help. the overseas contingents were in Medan City when they arrived until they returned to their respective countries.

f. The next form of the word propaganda persuasion is "Amenity".

Amenity is the availability and condition of existing facilities or provided for tourists during their trip. Here the meaning of amenity as stated in the framework of reference for the Medan City Tourism Office is intended as what the GeMeS event organizers provide in the context of carrying out activities for performing arts and cultural Malays, such as food stands and performance stands for songket cloth typical of Malay culture, micro-businesses, seats for all guests, stages, changing rooms and so on.

g. The form of the word propaganda persuasion found in other terms of reference is "The Malay Culture Study Project".

The meaning of this sentence is that the GeMeS event which from 2016-2019 was held based on a Malay cultural study project that has been implemented since 1972 . The basic concept remains the same, developing, extracting information, and preserving Malay culture so that later it will reach the next generation of Malay culture. will disappear in the swallow of the earth, following the Malay cultural slogan above"Malays will not disappear in the world".

h. Another form of persuasion propaganda that is mostly found in terms of reference, invitation letters to the Italian Ambassador, and the GeMeS Event brochure is the word "Serumpun".

The serumpun word in the Big Indonesian Dictionary means one ancestor or one lineage. In Malay culture, the word serumpun has the meaning of one unity, which 
means that even though they have different customs, different cultures of ethnic Malays still declare themselves to be a family when they meet other ethnic Malays. Therefore, in the invitation letter and the extension of the GeMeS event, the word serumpun means that the series of GeMeS events are only a series of activities that are Malay culture in nature. Then, the organization and participation of the contingent from within the city, outside the city, or abroad are people with ethnic Malay Culture or people and art workers who understand Malay culture.

Based on the results of this analysis, it can be concluded that the form of propaganda persuasion words or sentences in the invitation made by the Medan City Tourism Office is a form of confirmation of the GeMeS event which will be held in Medan City, starting from the meaning of the slogan, affirming the promotional language and all things given by the Medan City Tourism Office and received by tourists who are contingent for the GeMeS event.

Third, the language of educational persuasion. Persuasion Education is a persuasion paragraph that contains special messages that have to do with the world of education. This paragraph is commonly used by educational institutions that wish to convey a message that has something to do with the world of education, such as appeals, motivation to learn, educational guides, and so on.

In the research that has been conducted by researchers, it can be analyzed that the form of educational persuasion can be found in the invitation letter sent by the Medan City Tourism Office to the Italian Ambassador to be later translated and sent to the countries invited to participate in the GeMeS event as well as the terms of reference. Medan City Tourism Office. The form of the persuasion sentence or paragraph includes:The form of the sentence which refers to educational persuasion in the invitation letter to the Italian Ambassador is the sentence

a. "To preserve Malay arts and culture".

Here, what is meant by preserving is not only maintaining and managing, but preserving here is providing knowledge and knowledge to the public about the ins and outs of Malay art and culture to the world, such as dance performances, music arts, songket exhibitions, typical Malay food and so on.

b. Another form of sentence that refers to educational persuasion is found in the framework of reference for the Medan City Tourism Office at the GeMeS event on the "Background" indicator.

In this background, a summary of the Malay culture, starting from the basic words of Malay, ethnic Malays that spread in countries in the world, the definition of ethnic Malays in general, and the characteristics of the people who are classified into ethnic Malay and so on. The purpose of a summary of Malay culture, which is described, of course, is a medium of education to readers about a brief history of Malay culture.

Another form of sentence that refers to educational persuasion is also found in the framework of reference for the Medan City Tourism Office at the GeMeS event on the "Purpose and Purpose" indicator. In numbers one, two, and five, which specifically explains that the purpose of the GeMeS event is as a preservation medium, a medium for exchanging information and insights into Malay culture as well as a medium for appreciation and education for artists or art observers on Malay culture. With this in mind, of course, it is very clear that the aim of the GeMeS event is also to be an educational medium.

Based on the results of this analysis, it can be concluded that the form of the word or sentence of educational persuasion in the invitation made by the Medan City Tourism Office is a form of educational media by interpreting the word preserve in the invitation letter and the framework of reference. Also, by carrying out the exchange of Malay culture from various regions, provinces and countries, it is hoped that the future generations of the nation will be 
able to protect the culture and so that the Malay culture does not disappear with the development of the times.

\section{The Occurance of Persuasive Language in Gelar Melayu Serumpun (GeMeS)}

In this section, researcherwill describe research findings and analyze the persuasive language of promotional strategies found in brochures distributed via e-mail or social media related to the GeMeS event, including the following:

a. The Language of Advertising Persuasion

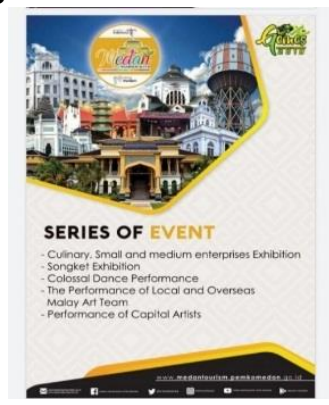

Data Sources: Research Results, 2020

Based on this "Series Of Event" brochure, it can be seen that all "Series Of Event" indicators are the language of advertising persuasion. This is because the indicators specifically listed show the promotional advertisements of the events the GeMeS event will hold to the public. With this information, the public can find out what series of events will be held later.

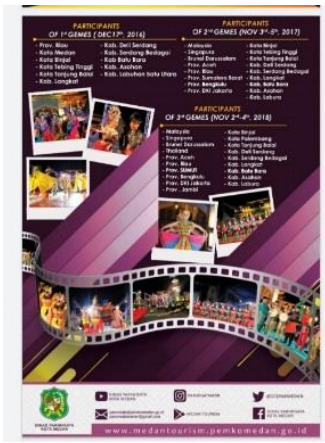

Data Sources: Research Results, 2020

The "Participant" brochure explains that the 2019 GeMes event promotion advertisement also describes which regions, provinces, and countries have participated in previous years. It should be noted that the main targets of the GeMeS Event in 2019 this time are India and Korea. Because from 2017-2018 countries such as Malaysia, Singapore, Brunei Darussalam, and Thailand have participated in the GeMeS event. However, at the time of sending the invitation letter, India and Korea had not responded well.

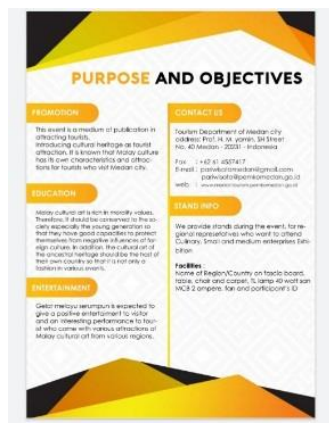

Data Sources: Research Results, 2020

In the "Purpose and Objectives" brochure, the persuasion paragraph of advertising is also visible on the "promotion" indicator with the content "This event is a medium of publication in attracting tourists. Introducing cultural heritage as a tourist attraction. It is known that the 
Malay culture has its characteristics and attractions for tourists who visit Medan city. It has also been explained here that this event was held to attract tourists and introduce Malay cultural heritage to the public. This is done because the Malay culture has unique characteristics that can attract tourists to visit.Then, still with the "Purpose and Objectives" brochure, the persuasion paragraph of advertising can also be seen in the "Contact Us" indicator, where this indicator explains to find out complete information related to the GeMeS event being held, so contingents from abroad can find out more detailed information with contact the contact listed.

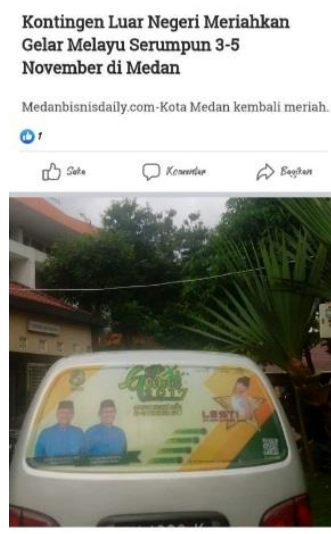

Data Sources: Research Results, 2020

Based on an article written by MedanBisnisDaily which researchers got from the official GeMeS account in 2017, it can be explained that the article affirms and advertises to the public that countries from abroad have participated in the participation of the GeMeS event. The purpose of this information being disseminated is as a form of information media and to convince the audience that the GeMeS event is not arbitrary, but classy and prestigious because it can present participants from abroad.

\section{b. The Language of Propaganda Persuasion}

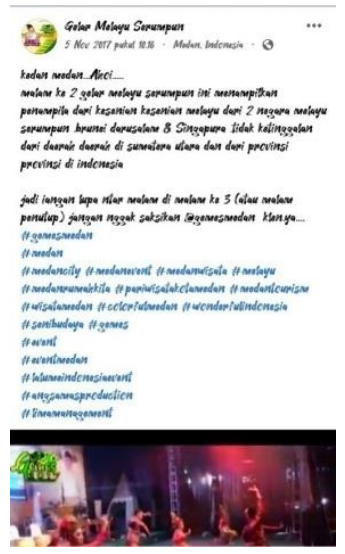

Data Sources: Research Results, 2020

Based on a post from the GeMeS Facebook social media account, there is the word "Kedan, Ahoy". Here the meaning of the word "Kedan" is a friend or friend for the people of Medan City. Meanwhile, the word "Ahoy" is a typical greeting designation of Malay culture. So when combined the word "Kedan, Ahoy" means a typical Malay greeting addressed to the people of Medan City to attend and watch GeMeS event performances. 


\section{c. The Language of Education Persuasion}

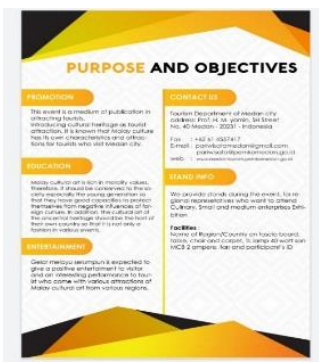

Data Sources: Research Results, 2020

Based on the brochure "Purpose and Objectives", educational persuasion sentences in this study are contained in the" Education "indicator. Education here is a form of explanation to the public that the GeMeS event is also intended as a medium of education, especially for the current generation. Where there have been a lot of foreign cultures that have influenced the younger generation. With the presence of a typical Malay arts and culture event, the Medan City Tourism Office hopes that in the future the younger generation will be able to recognize, preserve and develop Malay culture as a culture that has unique characteristics, various kinds of songket cloth, language, customs, religions, and others.

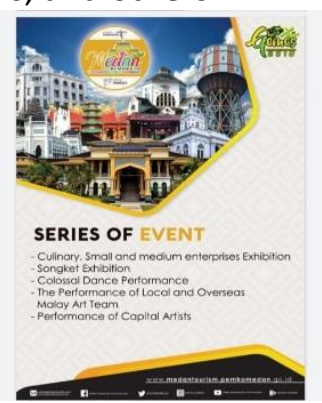

Data Sources: Research Results, 2020

The form of educational persuasion sentences in this study is contained in the brochure "Series Of Events" on the "Songket Exhibition" indicator. It can be seen that an exhibition is a show of a certain object which is shown to various kinds of public circles. Also, exhibitions are not only exhibiting in nature but can also be educational. This is because, from the objects that are displayed, there is information and knowledge that is useful in everyday life and as a treasury of knowledge in a person. Related to the research conducted by researcher, the songket exhibition and food exhibition displayed at the GeMeS event are not only showing. Instead, it provides education to the local people of Medan city and foreign tourists who are contingent for the GeMeS event that for Medan City and other provinces that have Malay ethnicity, the songket cloth made by the Malay community is not the same. There are differences in motifs, fabric materials, thread models, and others that can form certain meanings. With the songket exhibition being held, it can provide education and public knowledge of the types of songket cloth and the meaning of the symbols contained therein. 


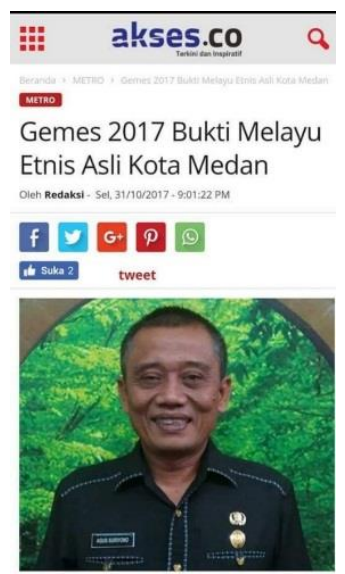

Data Sources: Research Results, 2020

Based on articles published by Akses.co. and then re-uploading it by the GeMeS Facebook account can educate the people of Medan City who don't know that the GeMeS event provides new information and knowledge that the Malays in Medan, North Sumatra are the original ethnic groups of Medan City. It should be noted that most of the people of Medan City and outside Medan City have a perception that the original ethnicity of Medan City, North Sumatra is Batak. Therefore, the Medan City Tourism Office wants to provide new education to the public that the original ethnicity of Medan City, North Sumatra is not only Batak but also ethnic Malays who have long controlled the coastal areas and Medan City

\section{Findings}

After analyzing and then describing the research results that have been found by the researcher, the researcher will conduct a discussion related to the theories put forward and related to the research results, including as follows:

The Medan City Tourism Office as an institution under the Government is an agency that manages tourism activities, ranging from development, infrastructure, conservation, education, and so on. One of the efforts to develop a tourism marketing strategy is to create a GeMes (Serumpun Malay Title) event which aims as a means of promoting Malay culture and establishing friendship in the arts and culture both with other regions and abroad.

The form of the marketing strategy carried out by the Medan City Tourism Office is included in the marketing distribution channel stage. Marketing distribution channels also play an important role in realizing the ideals of tourism development. Through advertising and public relations activities carried out by various agencies or organizations included in the marketing distribution channel group, ranging from travel agencies, event organizer service providers or others who are expected to build the image and promotion of the tourism destination. Promotional messages disseminated through advertisements and other promotional tools can influence expectations of the intended vision and can influence perceptions and levels of satisfaction and travel experience.

One form of preservation of Malay culture promoted by the Medan City Tourism Office is by holding a GeMeS event which will be held from 2016 to 2019. To carry out this implementation, the Medan City Tourism Office needs to hold a form of promotion so that the implementation of the GeMeS program can run smoothly. maximum and achieve the goals that have been set.

The basic reason the Medan City Tourism Office invites contingents from abroad to participate in the GeMeS event is that these countries are countries that have ethnic Malay communities that also preserve Malay culture. With the GeMeS event, the Medan City Tourism Department hopes to be able to preserve Malay culture globally and internationally, introduce 
typical Malay culture ranging from food, the exhibition of songket fabrics, songs, and dances and be able to add knowledge and knowledge about Malay culture from various regions and countries.

One form of promotion carried out by the Medan City Tourism Office is to invite regional, provincial, and foreign tourists to participate in the implementation of the GeMeS event, such as Malaysia, Brunei Darussalam, Thailand, and Singapore. The form of promotion is given by using an official invitation letter sent to the Italian Ambassador to be translated into English from being sent to the embassy of the invited country. After that, the Medan City Tourism Office will create a framework of reference so that the promotion, dissemination, and implementation process can run effectively.

The promotional language used to invite foreign tourists to participate in GeMeS events is by using persuasion language, where persuasive language specifically describes the promotion of GeMeS event which are advertising, propaganda, and education in nature. According to Tubbs and Moss in Mulyana, 2013: 65), persuasive language is a process of creating meaning between two or more people that involves giving meaning to these people. Persuasion language is also aimed at an attempt to change or encourage other people to change their behavior towards something.

Regarding the promotional invitation given, the persuasive language at the GeMeS event aims to invite domestic and foreign tourists to participate in the GeMeS event organized by the Medan City Tourism Office. The form of participation that was followed by contingents from within and outside the country was dance performances, songs, food, songket cloth, and souvenirs from both regions and countries that have Malay culture.

For overseas contingents, the reason they participated in the implementation of the GeMeS event was that the promotions provided by the Tourism Office attracted their attention, such as the facilities, infrastructure, and facilities provided by the organizers as long as the contenders from abroad were in Medan City. They felt benefited by the GeMeS event. They only need to spend funds for departure and return, but other facilities such as accommodation, hotels, food, and so on are covered by the local government of Medan City.

Besides, with a promotional language that is educational and invites people who have Malay culture abroad, it creates a deep sense of curiosity for overseas contingents. This is because basically, the Malay culture is unique to the Province of Sumatra, therefore with the invitation to participate in the GeMeS event, it indirectly provides opportunities for overseas contingents to study Malay culture more specifically.

\section{Conclusions}

After analyzing the data findings and conducting a discussion, the conclusions of this study are as follows:

1. Implementation of the persuasive language used in the promotion strategy of the Serumpun Malay Title (GeMeS), which is divided into three parts, namely advertising persuasion where the strategy is aimed at advertising and promotion to both overseas contingents and the public who are invited to participate in the GeMeS event. Then the propaganda persuasion, where in the promotion that is spread, words and language are inserted to emphasize the typical Malay culture as an identity that the GeMeS event is a tourism activity for the preservation of Malay culture. And educational persuasion, wherein the promotion of the GeMeS event organizers also hope that the holding of the GeMeS event can become a medium of exchange and educational media for the typical Malay culture of each region, province, and country starting from dances, songs, food, songket fabrics, and souvenirs.

2. The persuasive language of the GeMeS event organizers occurs by distributing various forms of promotional media such as brochures, articles, invitation letters, and so on. 
Then this promotional media is also spread through social media Facebook with the official GeMeS account. It aims to provide information and knowledge to the public more widely. Persuasive language is also carried out in three ways, the namely persuasive language of advertising which contains advertisements about any series of GeMeS events, the persuasive language of propaganda by writing either in brochures or social media posts slogans and typical Malay words and language. persuasive education by writing the words to preserve, cultivate, cultural exchange, and so on as a form of an invitation to enliven the GeMeS event.

\section{References:}

Hassan, Hanita. 2017. The Function Of Language Is Shaping Tourism Information. LSP International Journal : Vol.4 No.2.

Jalilifar, Alireza. Tourism Discourse Revisited: An Analysis Of Evaluative Strategies In Tourist brocures From A Systemic Linguistic Perspective. Journal Of English Studies : Vol. 17 No. 211-232.

Maulina, Fatia. 2018. Penggunaan Bahasa Persuasi Iklan Komersial di Televisi dan Implikasinya di SP. Jurnal Skripsi: Fakultas Keguruan dan Ilmu Pendidikan, Universitas Lampung.

Nainggolan, Vera Yoyeti et al. 2020. Penggunaan Bahasa Persuasif Dalam Iklan Niaga Bergambar Pada Surat Kabar Serambi Indonesia. Jurnal Samudra Bahasa: http/ejournalunm.index/phsb.

Sugiyono. 2013. Metode Penelitian Pendidikan: Pendekatan Kuantitatif, Kualitatif Dan R\&D. Bandung : CV. Alfabeta.

Tunggala, Suanti \& Saadjad, Ken Amasita. 2019. Strategi Komunikasi Pada Dinas Kebudayaan dan Pariwisata Dalam Mempromosikan Objek Wisata Kabupaten Banggai. Jurnal Komunikasi: Vo.11 No.02, ISSN 2085-1979. 